Article

\title{
In Vitro Anti-HIV-1 Reverse Transcriptase and Integrase Properties of Punica granatum L. Leaves, Bark, and Peel Extracts and Their Main Compounds
}

\author{
Cinzia Sanna ${ }^{1, *,+} \oplus$, Arianna Marengo ${ }^{2,+}$, Stefano Acquadro $^{2}$, Alessia Caredda ${ }^{3}$, Roberta Lai ${ }^{1}$, Angela Corona $^{3}{ }^{\circ}$,

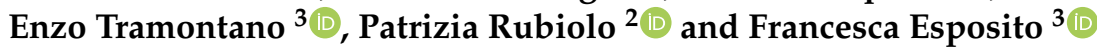 \\ 1 Laboratory of Pharmaceutical Botany, Department of Life and Environmental Sciences, University of Cagliari, \\ Via S. Ignazio da Laconi 13, 09123 Cagliari, Italy; roberta.lai@unica.it \\ 2 Department of Drug Science and Technology, University of Turin, Via Pietro Giuria 9, 10125 Turin, Italy; \\ arianna.marengo@unito.it (A.M.); stefano.acquadro@alice.it (S.A.); patrizia.rubiolo@unito.it (P.R.) \\ 3 Laboratory of Molecular Virology, Department of Life and Environmental Sciences, University of Cagliari, \\ Cittadella Universitaria di Monserrato, ss554, km 4500, Monserrato, 09042 Cagliari, Italy; \\ alessiacaredda@unica.it (A.C.); angela.corona@unica.it (A.C.); tramon@unica.it (E.T.); \\ francescaesposito@unica.it (F.E.) \\ * Correspondence: cinziasanna@unica.it \\ + These authors contributed equally.
}

Citation: Sanna, C.; Marengo, A.; Acquadro, S.; Caredda, A.; Lai, R.; Corona, A.; Tramontano, E.; Rubiolo, P.; Esposito, F. In Vitro Anti-HIV-1 Reverse Transcriptase and Integrase Properties of Punica granatum L. Leaves, Bark, and Peel Extracts and Their Main Compounds. Plants 2021, 10, 2124. https://doi.org/10.3390/ plants10102124

Academic Editor: Maria José U. Ferreira

Received: 15 September 2021

Accepted: 2 October 2021

Published: 7 October 2021

Publisher's Note: MDPI stays neutral with regard to jurisdictional claims in published maps and institutional affiliations.

Copyright: (c) 2021 by the authors. Licensee MDPI, Basel, Switzerland. This article is an open access article distributed under the terms and conditions of the Creative Commons Attribution (CC BY) license (https:// creativecommons.org/licenses/by/ $4.0 /)$.

\begin{abstract}
In a search for natural compounds with anti-HIV-1 activity, we studied the effect of the ethanolic extract obtained from leaves, bark, and peels of Punica granatum L. for the inhibition of the HIV-1 reverse transcriptase (RT)-associated ribonuclease H (RNase H) and integrase (IN) LEDGFdependent activities. The chemical analyses led to the detection of compounds belonging mainly to the phenolic and flavonoid chemical classes. Ellagic acid, flavones, and triterpenoid molecules were identified in leaves. The bark and peels were characterized by the presence of hydrolyzable tannins, such as punicalins and punicalagins, together with ellagic acid. Among the isolated compounds, the hydrolyzable tannins and ellagic acid showed a very high inhibition $\left(\mathrm{IC}_{50}\right.$ values ranging from 0.12 to $1.4 \mu \mathrm{M}$ and 0.065 to $0.09 \mu \mathrm{M}$ of the RNase $\mathrm{H}$ and IN activities, respectively). Of the flavonoids, luteolin and apigenin were found to be able to inhibit RNase $\mathrm{H}$ and IN functions ( $\mathrm{IC}_{50}$ values in the 3.7-22 $\mu \mathrm{M}$ range), whereas luteolin 7-O-glucoside showed selective activity for HIV-1 IN. In contrast, betulinic acid, ursolic acid, and oleanolic acid were selective for the HIV-1 RNase H activity. Our results strongly support the potential of non-edible $P$. granatum organs as a valuable source of anti-HIV-1 compounds.
\end{abstract}

Keywords: Punica granatum; pomegranate; leaves; bark; peel; HIV-1 reverse transcriptase; HIV-1 integrase; ellagic acid; hydrolyzable tannins; triterpenoids

\section{Introduction}

Punica granatum L. (Pomegranate) is a shrub or small tree belonging to the Lythraceae family that originated from Central Asia, from where it spread to the rest of the world [1]. Since ancient times, it has been cultivated in the Mediterranean region. Today, over 500 varieties are recognized [2]. Pomegranate fruits, pericarp, flowers, and root bark have been used to treat a variety of ailments in Chinese, Ayurvedic, Islamic, and Persian medicine $[1,3,4]$. More recently, it has been considered a functional food due to a variety of active components, including tannins, alkaloids, organic acids, flavonoids, and terpenes [2], endowed with a wide range of pharmacological effects. Interestingly, the nutraceutical value is not limited to the fruits; in fact, the non-edible fractions of the fruits and tree (peels, seeds, bark, and leaves), which are discarded or disregarded, might be a valuable source of phytochemicals [5,6], promoting the exploitation and valorization of agricultural wastes and byproducts enriched in high added-value molecules [7]. Fruits (peel and juice) are 
rich in phenolic compounds, including flavonoids and hydrolyzable tannins (punicalin, pedunculagin, punicalagin, gallic acid, and ellagic acid), and flavonols (quercetin and myricetin) $[1,8]$. Moreover, anthocyanins, such as pelargonidin, cyanidin, and delphinidin glucosides, have been reported in both edible and inedible parts of fruits $[9,10]$. In addition to the hydrolyzable tannins identified in fruit peel, bark contains C-glycosidic ellagitannins, such as punicacorteins A-D, punigluconin, casuariin, and casuariniin [11], and dimeric gallic acid glycosides [12]. Leaves contain many gallic acid derivatives, also known as gallotannins and ellagitannins $[3,13]$, and phenolics and flavone glycosides $[3,14]$. Both qualitative and quantitative differences have been observed in different pomegranate cultivars $[9,15]$ as well as seasonal changes in their content [16]. Due to its bioactive compounds, pomegranate possesses antioxidant, anti-inflammatory, antidiabetic, anticancer, antimicrobial, cardioprotective, and neuroprotective effects [1,5,6,17-21]. Antiviral properties against human herpes virus 3 (HHV-3) [22], herpes simplex virus 2 (HSV-2) [23], influenza virus [24], and enterovirus 71 [25] have been reported and, recently, Acquadro et al. 2020 [14] tested the extract of pomegranate leaves from Sardinia for its antiviral properties against Zika virus. Moreover, pomegranate fruit juice contains molecules that target the virus envelope and are able to prevent HIV-1 binding to the cellular receptor CD4 and CXCR4/CCR5 [26]. Despite the availability of many target-specific anti-HIV-1 drugs, their efficacy is often compromised by their toxicity and the selection of drug-resistant viral strains. Therefore, the discovery of new compounds with a novel mechanism of action is needed. In this context, the development of multi-target inhibitors would provide a relevant aid $[27,28]$.

With the aim of finding plant compounds that function as dual HIV-1 inhibitors, in this study we investigated the ability of ethanol extracts and pure compounds obtained from leaves, bark, and peel of P. granatum to inhibit in enzymatic assays the HIV-1 reverse transcriptase (RT)-associated ribonuclease $\mathrm{H}(\mathrm{RNase} \mathrm{H})$ activity, an attractive target for which there is currently no approved drug [29-31]. Therefore, considering its similarity to RNase H [31], the inhibition of integrase (IN) in the presence of the LEDGFp75 cellular cofactor was also evaluated. Due to its pivotal role in virus replication, the interaction between LEDGF/p75 and IN is an attractive target for a novel anti-retroviral strategy. In fact, LEDGFp75 tethers IN associated with the viral genome to the host chromatin, promoting the integration process [32,33]. Interestingly, extensive depletion of LEDGF/p75 levels was correlated to a significant decrease in HIV-1 infectivity.

\section{Results and Discussion}

Fruits, peel, and bark of P. granatum have been used in traditional medicine to treat a variety of ailments. The great interest in the medicinal and nutritional value of pomegranate is documented by the $>1500$ articles on its health effects that have been published to date. However, despite the relatively large amount of literature on pomegranate fruits (juice and peel), much less information is available regarding the other organs. In our search for anti-HIV-1 agents from plants [28,34-39], we firstly tested the ethanolic extracts obtained from the leaves (PGL), bark (PGB), and peels (PGP) of P. granatum from Sardinia for their ability to inhibit the RT-associated RNase $\mathrm{H}$ activity. This is regarded as an attractive and innovative target, since even though the majority of anti-AIDS molecules available for therapy are represented by RT inhibitors, all of them inhibit its associated DNA polymerase activity. Subsequently, considering the high degree of structural homology between the RNase H catalytic core and HIV-1 IN [29], the inhibition of the HIV-1 IN strand transfer reaction in the presence of LEDGF/p75 was also evaluated. In fact, compounds inhibiting the HIV-1 RNase H activity may also influence the HIV-1 IN activity [30]. The development of dual inhibitors, i.e., single molecules targeting more than one enzyme function, has recently been proposed as an original approach, since it potentially reduces the side effects associated with the coadministration of different classes of drugs [40,41]. 
2.1. Anti-HIV-1 Activity of Ethanolic Extracts Obtained from P. granatum Bark (PGB), Leaves (PGL), and Fruit Peels (PGP)

All the pomegranate extracts showed a strong inhibitory activity on both enzymes, with $\mathrm{IC}_{50}$ values ranging from 0.22 to $0.85 \mu \mathrm{g} / \mathrm{mL}$ on HIV-1 RT RNase $\mathrm{H}$ activity and from 0.12 to $0.5 \mu \mathrm{g} / \mathrm{mL}$ on HIV-1 IN LEDGF-dependent activity, respectively (Table 1).

Table 1. Effect of P. granatum extracts on the HIV-1 RT-associated RNase H function and Integrase activity in the presence of LEDGF.

\begin{tabular}{lcc}
\hline \multicolumn{1}{c}{ Extracts/Pure Compounds } & $\begin{array}{c}\text { HIV-1 RT-Associated } \\
\text { RNase H } \\
\text { IC }_{\mathbf{5 0}}(\boldsymbol{\mu g} / \mathbf{m L})^{\mathbf{a}}\end{array}$ & $\begin{array}{c}\text { HIV-1 Integrase } \\
\text { LEDGF-Dependent } \\
\text { IC }_{\mathbf{5 0}}(\boldsymbol{\mu g} / \mathbf{m L})\end{array}$ \\
\hline Punica granatum leaves extract (PGL) & $0.61 \pm 0.02$ & $0.12 \pm 0.065$ \\
\hline Punica granatum bark extract (PGB) & $0.22 \pm 0.04$ & $0.18 \pm 0.02$ \\
\hline Punica granatum peel extract (PGP) & $0.85 \pm 0,01$ & $0.5 \pm 0.035$ \\
\hline RDS1759 & $10.7 \pm 0.9^{\mathrm{c}}$ & - \\
\hline Raltegravir & - & $0.058 \pm 0.01^{\mathrm{c}}$
\end{tabular}

${ }^{\mathrm{a}}$ Extract concentration required to reduce the HIV-1 RT-associated RNase $\mathrm{H}$ activity by $50 \%{ }^{\mathrm{b}}$ Extract concentration required to inhibit the HIV-1 IN catalytic activity by $50 \%$ in the presence of LEDGF. ${ }^{c}$ Compound concentration expressed in $\mu \mathrm{M}$.

Among the three extracts, PGB exerted the highest inhibitory activity against HIV-1 RT RNase H, followed by PGL and PGP. On the other hand, PGL was more active against HIV-1 IN LEDGF-dependent activity, followed by PGB and PGP.

\subsection{Phytochemical Study of Punica granatum Extracts}

In order to identify the main compounds in PGL, PGB, and PGP extracts, a phytochemical study was undertaken. HPLC-PDA-MS/MS analyses evidenced compounds belonging to the phenolic and flavonoid chemical classes (Figure 1).<smiles>O=c1oc2c(O)c(O)cc3c(=O)oc4c(O)c(O)cc1c4c23</smiles>

ellagic acid<smiles>OCC1OC(Oc2ccc(-c3cc(O)c4cc(O)cc(O)c4c3)cc2O)C(O)C(O)C1O</smiles>

luteolin $4^{\prime}$-O-glucoside

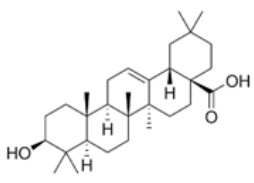

oleanolic acid<smiles>O=c1cc(-c2ccc(O)c(O)c2)oc2cc(O)cc(O)c12</smiles>

luteolin<smiles>CC(CO)C(O)Oc1cc(O)c2c(=O)cc(-c3ccc(O)c(O)c3)oc2c1</smiles>

luteolin 7-O-glucoside

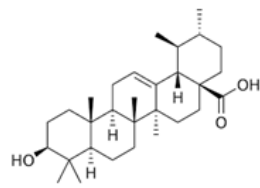

ursolic acid

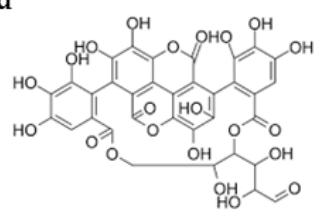

punicalin<smiles>O=c1cc(-c2ccc(O)cc2)oc2cc(O)cc(O)c12</smiles>

apigenin

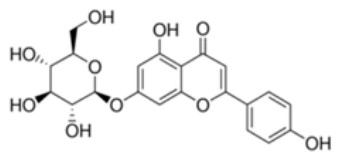

apigenin 7-O-glucoside

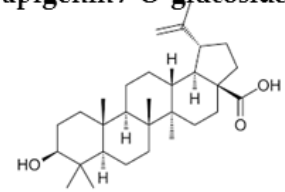

betulinic acid

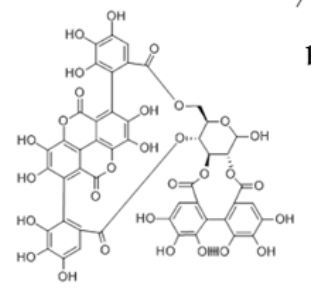

punicalagin

Figure 1. Compounds detected in leaves, bark, and fruit peel ethanolic extracts of P. granatum L. 
A list of the identified and putatively identified compounds in the PGB and PGP extracts is shown in Table 2. The representative compounds in the PGL extract were reported in Acquadro et al. 2020 [14].

Table 2. Identified and hypothesized compounds in PGB and PGP extracts. For each compound, the relative retention time (RT), maximum absorption (nm), molecular formula, pseudomolecular ions (ESI ${ }^{+}$and $\mathrm{ESI}^{-}$), fragments obtained in product ion scan mode (PIS), and identified or putatively identified compound names are indicated. The identification confidence value and the bibliography reference related to the detected compounds in pomegranate are also reported.

\begin{tabular}{|c|c|c|c|c|c|c|c|c|c|c|c|}
\hline $\mathbf{N}^{\circ}$ & RT & $\begin{array}{c}\lambda \max \\
(\mathrm{nm})\end{array}$ & $\begin{array}{l}\text { Molecular } \\
\text { Formula }\end{array}$ & {$[\mathbf{M}+\mathbf{H}]^{+}$} & {$[\mathbf{M}-\mathbf{H}]^{-}$} & $\begin{array}{l}\text { Supposed } \\
\text { MW }\end{array}$ & $\begin{array}{c}\mathrm{MS}^{2+} \\
m / z\end{array}$ & $\begin{array}{c}\mathrm{MS}^{2-} \\
m / z\end{array}$ & $\begin{array}{l}\text { Compound } \\
\text { Name }\end{array}$ & $\begin{array}{c}\text { Identif. } \\
\text { Confidence a }\end{array}$ & Ref. \\
\hline 1 & 2.076 & $257 / 377$ & $\mathrm{C}_{34} \mathrm{H}_{22} \mathrm{O}_{22}$ & 783 & 781 & 782 & 603 & 601 & $\underset{\beta}{\text { Punicalin } \alpha+}$ & 1 & [42] \\
\hline 2 & 4.414 & $258 / 376$ & $\mathrm{C}_{48} \mathrm{H}_{28} \mathrm{O}_{30}$ & 1085 & 1083 & 1084 & 603 & 601 & $\begin{array}{l}\text { Punicalagin } \\
\text { isomer }\end{array}$ & 2 & [43] \\
\hline 3 & 6.553 & $257 / 370$ & $\mathrm{C}_{21} \mathrm{H}_{10} \mathrm{O}_{13}$ & 471 & 469 & 470 & $\begin{array}{l}453,407 \\
151,363\end{array}$ & $\begin{array}{l}451,425 \\
353,341\end{array}$ & $\begin{array}{l}\text { Valoneic acid } \\
\text { dilactone }\end{array}$ & 2 & {$[44]$} \\
\hline 4 & 7.984 & $257 / 376$ & $\mathrm{C}_{48} \mathrm{H}_{28} \mathrm{O}_{30}$ & 1085 & 1083 & 1084 & 621,603 & 601 & $\begin{array}{c}\text { Punicalagin } \\
\alpha\end{array}$ & 1 & [42] \\
\hline 5 & 11.853 & $257 / 380$ & $\mathrm{C}_{48} \mathrm{H}_{28} \mathrm{O}_{30}$ & 1085 & 1083 & 1084 & $\begin{array}{c}765,621 \\
603\end{array}$ & $\begin{array}{l}781,721 \\
301\end{array}$ & $\begin{array}{c}\text { Punicalagin } \\
\beta\end{array}$ & 1 & [42] \\
\hline 6 & 18.842 & $252 / 360$ & $\mathrm{C}_{20} \mathrm{H}_{16} \mathrm{O}_{13}$ & 465 & 463 & 464 & $\begin{array}{c}345,315 \\
303,285 \\
223\end{array}$ & 301,283 & $\begin{array}{l}\text { Ellagic acid } \\
\text { glucoside }\end{array}$ & 2 & [45] \\
\hline 7 & 21.931 & $254 / 364$ & $\mathrm{C}_{21} \mathrm{H}_{10} \mathrm{O}_{13}$ & 471 & 469 & 470 & $\begin{array}{l}407,303, \\
168,139\end{array}$ & $\begin{array}{c}301,271 \\
227,201 \\
171\end{array}$ & $\begin{array}{c}\text { Sanguisorbic } \\
\text { acid } \\
\text { dilactone }\end{array}$ & 2 & [46] \\
\hline 8 & 22.859 & $252 / 364$ & & 435 & 433 & 434 & $\begin{array}{c}303,285 \\
275\end{array}$ & 301 & $\begin{array}{l}\text { Ellagic acid } \\
\text { derivative }\end{array}$ & 3 & \\
\hline 9 & 23.613 & $251 / 360$ & $\mathrm{C}_{19} \mathrm{H}_{14} \mathrm{O}_{12}$ & 435 & 433 & 434 & 303,285 & 301,283 & $\begin{array}{l}\text { Ellagic acid- } \\
\text { pentoside }\end{array}$ & 2 & [42] \\
\hline 10 & 24.279 & $251 / 360$ & $\mathrm{C}_{20} \mathrm{H}_{16} \mathrm{O}_{12}$ & 449 & 447 & 448 & $\begin{array}{c}303,285 \\
273\end{array}$ & $\begin{array}{c}301,257 \\
229\end{array}$ & $\begin{array}{l}\text { Ellagic acid } \\
\text { deoxyhexo- } \\
\text { side }\end{array}$ & 2 & [45] \\
\hline 11 & 25.409 & $255 / 373$ & & 1067 & 1065 & 1066 & 603,575 & / & Ellagitannin & 3 & \\
\hline 12 & 25.658 & $252 / 366$ & $\mathrm{C}_{14} \mathrm{H}_{6} \mathrm{O}_{8}$ & 303 & 301 & 302 & / & $\begin{array}{c}284,229 \\
185\end{array}$ & Ellagic acid & 1 & [42] \\
\hline 13 & 25.934 & $255 / 372$ & & & 301 & & & $\begin{array}{l}275,256 \\
127\end{array}$ & Ellagitannin & 3 & \\
\hline 14 & 27.309 & $256 / 379$ & $\mathrm{C}_{28} \mathrm{H}_{10} \mathrm{O}_{16}$ & & 601 & & & 101 & $\begin{array}{l}\text { Gallagic acid } \\
\text { dilactone }\end{array}$ & 2 & [46] \\
\hline
\end{tabular}

a Identification confidence is based on CAWG (2007) [47]: Level 1: Identified compound (at least two independent orthogonal data values, such as retention time and mass spectrum, in accordance with an authentic reference standard); Level 2: Tentatively characterized compound (a compound identified by a comparison of spectral data and bibliographic data); Level 3: Putatively annotated class compound; Level 4: unknown compound.

According to the literature, ellagic acid is the most abundant specialized metabolite in pomegranate leaves, together with flavones, particularly luteolin and apigenin glycosides [20,48]. Moreover, the presence of triterpenoid molecules was confirmed by GC-MS analyses of the derivatized extract, which led to the identification of oleanolic acid, betulinic acid, and ursolic acid.

Bark and peels were characterized, in accordance with the available data [1,11], by the presence of hydrolyzable tannins together with ellagic acid (Figure 2). 


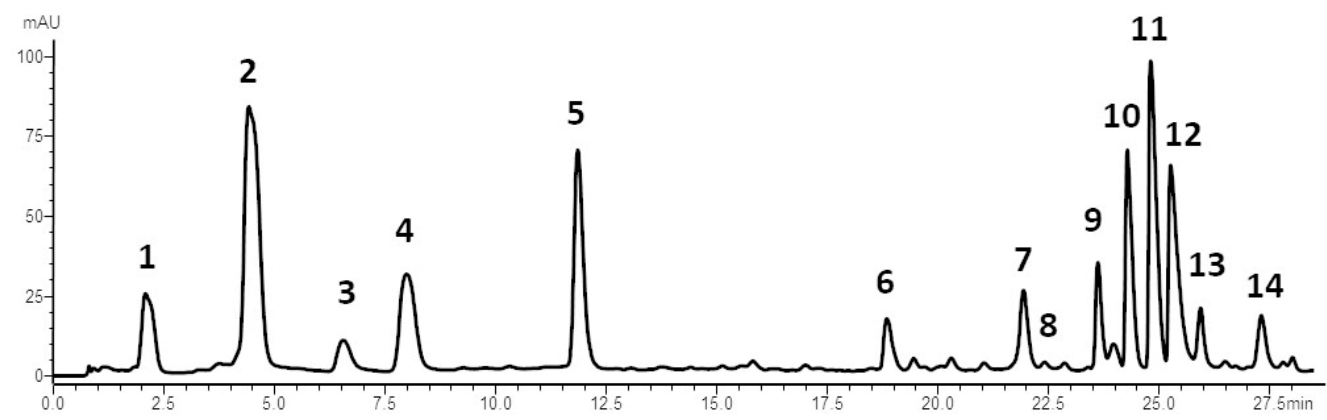

(a)

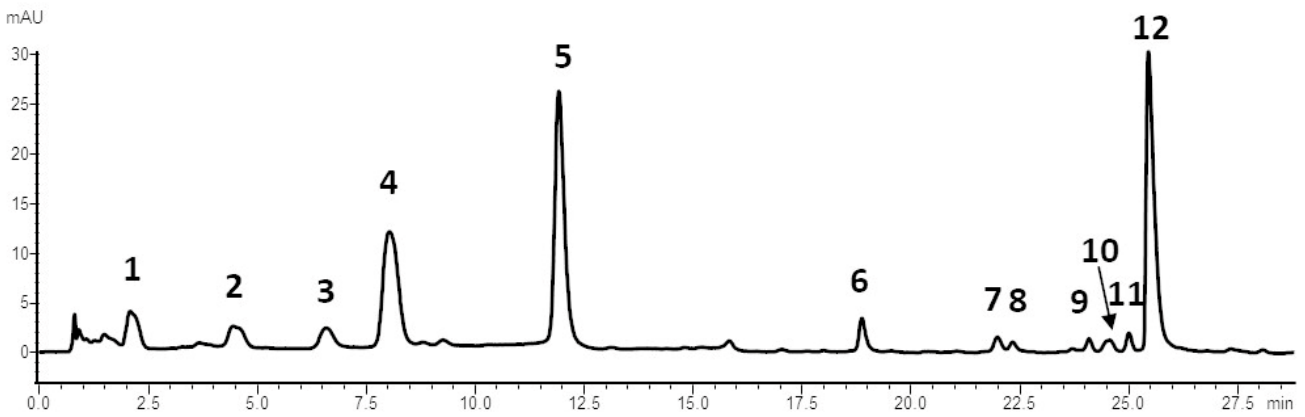

(b)

Figure 2. Chromatographic profiles of PGB (a) and PGP (b) $(\lambda=370 \mathrm{~nm})$. The compounds are numbered according to Table 2.

In particular, punicalagins and punicalins, which were not detected in leaves, are considered to be markers of these plant organs. Punicalagin isomers are known to constitute up to $85 \%$ of the total tannins extracted from pomegranate fruit peels [15].

A comparison of the PGF, PGB, and PGP LC-PDA profiles is reported in Figure S1.

\subsection{Anti-HIV-1 Activity of Pure Compounds Detected in PGB, PGL, and PGP}

To verify the contribution of individual identified components of the pomegranate leaves, bark, and peel extracts to the inhibition of HIV-1 RT-associated RNase H and IN LEDGF-dependent activities, their effect on these enzymes was evaluated and their $\mathrm{IC}_{50}$ values are shown in Table 3.

Table 3. Effect of P. granatum extracts on the HIV-1 RT-associated RNase H function and Integrase activity in the presence of LEDGF.

\begin{tabular}{|c|c|c|}
\hline Pure Compounds & 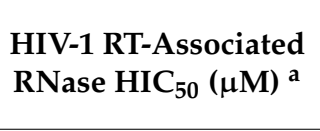 & $\begin{array}{l}\text { HIV-1 Integrase } \\
\text { LEDGF-Dependent } \\
\text { IC }_{50}(\mu \mathrm{M})^{b}\end{array}$ \\
\hline Ellagic acid & $1.4 \pm 0.11$ & $0.075 \pm 0.0005$ \\
\hline Luteolin & $3.7 \pm 0.5$ & $6.5 \pm 0.5$ \\
\hline Apigenin & $16.1 \pm 0.6$ & $22 \pm 3.5$ \\
\hline Luteolin $4^{\prime}$-O-glucoside & $>100(100 \%)^{c}$ & $>100(100 \%)^{c}$ \\
\hline Luteolin 7-O-glucoside & $>100(100 \%)^{\mathrm{c}}$ & $8.5 \pm 1.4$ \\
\hline Apigenin 7-O-glucoside & $>100(100 \%)^{c}$ & $>100(100 \%)^{c}$ \\
\hline Oleanolic acid & $6.7 \pm 0.4$ & $>100(74 \%)^{\mathrm{c}}$ \\
\hline Ursolic acid & $5.7 \pm 0.1$ & $>100(68 \%)^{c}$ \\
\hline Betulinic acid & $2.0 \pm 0.2$ & $96.5 \pm 3.5$ \\
\hline Punicalins & $0.18 \pm 0.03$ & $0.09 \pm 0.01$ \\
\hline Punicalagins & $0.12 \pm 0.00$ & $0.065 \pm 0.00$ \\
\hline
\end{tabular}

${ }^{\mathrm{a}}$ Compound concentration required to reduce the HIV-1 RT-associated RNase $\mathrm{H}$ activity by $50 \% .{ }^{\mathrm{b}}$ Compound concentration required to inhibit the HIV-1 IN catalytic activity by $50 \%$ in the presence of LEDGF. ${ }^{\mathrm{c}}$ Percentage of control activity measured in the presence of the indicated drug concentration. 
Consistent with our findings, effects of ellagic acid on HIV-1 IN activity have previously been observed [49,50]. Ellagic acid was also found to be able to suppress the replication of X4-tropic HIV-1 in the target cells without cytotoxicity [50]. This compound was also reported to have the ability to inhibit HIV-1 protease expression [51]. Differently from our results, Nutan et al. 2013 [51] reported the inability of ellagic acid to inhibit HIV RT. However, they assayed the ability of ellagic acid to inhibit RT DNA polymerase activity, not RNase $\mathrm{H}$ activity. This is a possible reason for the discrepancy with respect to our data on HIV RT inhibitory activity.

Luteolin and apigenin, two flavones detected in the PGL extract, were found to be active on both HIV-1 enzymes, showing $\mathrm{IC}_{50}$ values of $3.7 \mu \mathrm{M}$ and $16.1 \mu \mathrm{M}$ for RNase $\mathrm{H}$ activity and $6.5 \mu \mathrm{M}$ and $22 \mu \mathrm{M}$ for HIV-1 IN LEDGF-dependent activity, respectively, in agreement with our previous studies [38] although we found a lower degree of inhibition compared with ellagic acid and the control. Flavonoids are a class of natural compounds endowed with a broad spectrum of biological activities, including anti-SARS-CoV-2 activity [52] and promising anti-HIV-1 properties [53,54]. Interestingly, luteolin was found to be capable of inhibiting HIV-1 infection in Jurkat cells, showing better inhibition when added after HIV-1 infection, indicating that it exerts antiviral activity in the later stages of the HIV-1 lifecycle [55].

Recently, some flavonoid-based HIV-1 IN inhibitors targeting both the active site and the interaction with LEDGF/p75 were designed by introducing hydrophobic moieties into the flavanol core [56]. Out of the three luteolin and apigenin glycosides identified in PGL, only luteolin 7-O-glucoside was able to inhibit the HIV-1 IN LEDGF-dependent activity, with an $\mathrm{IC}_{50}$ value of $8.5 \mu \mathrm{M}$, showing a selective profile for this enzyme, while luteolin $4^{\prime}$-O-glucoside and apigenin 7-O-glucoside were found to be totally inactive at the highest tested concentration (Table 3). The three triterpenes, oleanolic acid, ursolic acid, and betulinic acid, identified in PGL were able to inhibit RT-associated RNase H activity, with $\mathrm{IC}_{50}$ values in the $2-7 \mu \mathrm{M}$ range, whereas they were found to be inactive, or weakly active in the case of betulinic acid, on the HIV-1 IN LEDGF-dependent activity. Betulinic acid has previously been reported to inhibit different steps of the HIV-1 lifecycle [57,58]. In particular, it inhibited HIV-1 RT-associated functions of both wild-type and mutant RTs [35]. Since their structures are partially correlated, betulinic acid, oleanolic acid, ursolic acid, and some of their derivatives were identified as anti-HIV principles, even though ursolic acid is slightly toxic [59]. Moreover, ursolic acid and oleanolic acid have been reported to inhibit protease expression [60,61].

Punicalins and punicalagins, which were detected in both PGB and PGP extracts, were found to be able to inhibit both enzymes and, in particular, the HIV-1 IN LEDGF-dependent activity, with $\mathrm{IC}_{50}$ values comparable to those exhibited by Raltegravir, which was used as a positive control. These compounds inhibited HIV-1 replication in infected H9 lymphocytes with a low degree of cytotoxicity [62]. In particular, punicalins have been found to be able to inhibit RT-associated RNase H activity [63] and to block the binding of HIV rgpl20 to CD4 [64].

Our findings suggest the possible utilization of non-edible organs of $P$. granatum as a source of valuable therapeutic agents. Interestingly, of the specialized metabolites identified, ellagic acid, luteolin, apigenin, punicalins, and punicalagins, whose quantitative data in PGL, PGB, and PGP extracts are reported in Table 4, could be used in the development of new multi-target drugs, since they are capable of inhibiting both HIV-1 enzymes. In fact, they represent a starting point for the development of new chemical derivatives whose modification could lead to new compounds with a multi-target function. 
Table 4. Quantitative analysis of compounds in pomegranate extracts characterized by inhibitory activities towards RT-associated HIV-1 RNase H and HIV-1 integrase LEDGF-dependent strand transfer.

\begin{tabular}{ccccccc}
\hline Compounds & \multicolumn{2}{c}{ PGL } & \multicolumn{2}{c}{ PGB } & \multicolumn{2}{c}{ PGP } \\
\hline & $\mathrm{mg} / \mathrm{g}^{1}$ & $\mathrm{RSD} \%$ & $\mathrm{mg} / \mathrm{g}$ & $\mathrm{RSD} \%$ & $\mathrm{mg} / \mathrm{g}$ & $\mathrm{RSD} \%$ \\
\hline Ellagic acid & 31.06 & 0.37 & 22.65 & 2.67 & 16.81 & 0.21 \\
\hline Luteolin & $\mathrm{Tr}^{3}$ & $/$ & $/$ & $/$ & $/$ & $/$ \\
\hline Apigenin & $\mathrm{Tr}^{3}$ & $/$ & $/$ & $/$ & $/$ & $/$ \\
\hline Punicalin $\alpha+\beta$ & $/$ & $/$ & 15.80 & 0.78 & 2.51 & 0.24 \\
\hline Punicalagin $\alpha+\beta$ & $/$ & $/$ & 76.06 & 0.75 & 29.51 & 0.25 \\
\hline
\end{tabular}

${ }^{1} \mathrm{mg}$ of quantified compound/g of extract; ${ }^{2} \mathrm{RDS} \%$, relative standard deviation; ${ }^{3} \mathrm{Tr}$, traces $<0.05 \mathrm{mg} / \mathrm{g}$.

\section{Materials and Methods}

\subsection{Plant Material}

Fresh leaves, bark, and fruit peel of $P$. granatum were collected from the botanical garden of the University of Cagliari (Sardinia, Italy). Samples were authenticated by Dr. Cinzia Sanna from the Department of Life and Environmental Sciences, where a voucher specimen (Herbarium CAG 514/A) was deposited. Plant material was dried in a ventilated stove at $40{ }^{\circ} \mathrm{C}$ to constant weight.

\subsection{Chemicals}

HPLC-grade methanol, LC-MS-grade acetonitrile, formic acid ( $>98 \%$ purity), pyridine, BSTFA, ellagic acid, rutin, and apigenin were obtained from Merck (Darmstadt, Germany). De-ionized water $(18.2 \mathrm{M} \Omega \mathrm{cm}$ ) was supplied by a Milli-Q purification system (Millipore). Luteolin, luteolin 7-O-glucoside, luteolin $4^{\prime}$-O-glucoside, apigenin 7-O-glucoside, quercetin 3-O-glucoside, betulinic acid, oleanolic acid, and ursolic acid were purchased from Extrasynthese (Genay, France). Punicalin $\alpha+\beta$ and punicalagin $\alpha+\beta$ were obtained from Phytolab (Vestenbergsgreuth, Germany).

The reagents used for expression, purification, and biochemical assays were purchased from Microbiol (Sardinia, Italy), Sigma-Aldrich (Milano, Italy), and PerkinElmer (Milano, Italy). The reference compound Raltegravir was purchased from ChemScene (Monmouth Junction, United States), while the reference compound RDS1759 was kindly provided by Prof. Roberto Di Santo (University of Rome La Sapienza). Recombinant proteins were purified using a Biological LP chromatography system (Biorad).

\subsection{Extraction and Detection of Active Compounds}

Dried leaves (115 g), bark (150 g), and peel (100 g) of P. granatum were separately ground in an electric grinder and the obtained powder was extracted with $1 \mathrm{~L}$ of $\mathrm{EtOH}$ $100 \%$ for $8 \mathrm{~h}$. The procedure was repeated three times. The extracts were then combined, filtered, and evaporated to obtain crude extracts ( $13.9 \mathrm{~g}$, $3.5 \mathrm{~g}$, and $10.4 \mathrm{~g}$, respectively). The characterization of the pomegranate extracts was carried out by HPLC-PDA-MS/MS using a Shimadzu Nexera X2 system coupled to an SPD-M20A photodiode array detector connected in series to a Shimadzu LCMS-8040 triple quadrupole system equipped with an ESI source (Shimadzu) under the operation conditions described in [14]. The main components were identified by comparison of MS fragmentation data with those reported in the literature and, when available, with the co-injection of the relative commercial standards. The quantitative data were obtained through an external calibration curve acquired via UV (at the $\lambda$ max for each compound) and single reaction monitoring (SRM) acquisition in $\mathrm{ESI}^{+}$(collision energy, $35.0 \mathrm{~V}$; dwell time, 20). The quantitative parameters are reported in Table S1.

GC-MS analyses were carried out on pomegranate leaf extracts after derivatization with bis(trimethylsilyl)trifluoroacetamide to obtain trimethylsilyl derivatives, as reported 
by Rubiolo et al. 2013 [64]. The GC-MS characteristics and operation conditions have previously been described in Acquadro et al. 2020 [14].

\subsection{Expression and Purification of Recombinant HIV-1 RT}

HIV-1 group M subtype B heterodimeric RT was expressed and purified essentially as previously described $[65,66]$.

\subsection{Expression and Purification of Recombinant HIV-1 IN and LEDGF/p75 Proteins}

Recombinant IN and LEDGF/p75 proteins were expressed and purified as described by Esposito et al. 2020 [67].

\subsection{RNase H Polymerase Independent Cleavage Assay}

HIV RT-associated RNase $\mathrm{H}$ activity was measured as described by Corona et al. 2016 [68] using the RNase H inhibitor RDS1759 as a control. Data analysis of the assay results was performed using GraphPad Prism 9.

\subsection{Homogeneous Time-Resolved Fluorescence (HTRF) IN LEDGF-Dependent Assay}

The IN activity was measured in the presence of LEDGF/p75 cellular cofactor in an HTRF assay $[69,70]$. Data analysis of the assay results was performed using GraphPad Prism 9.

\section{Conclusions}

This study reports the significant anti-HIV-1 activity of crude extracts and pure compounds detected in Punica granatum leaves, bark, and peel. Phytochemical investigation led to identification of the main compounds, which are, according to the available literature, hydrolyzable tannins, phenolics and flavone glycosides, and triterpenoids. Of the identified specialized metabolites, ellagic acid, punicalins, and punicalagins exhibited the most relevant inhibition of RT-associated HIV-1 RNase H and HIV-1 IN LEDGF-dependent activities. Consistent with the literature data, the betulinic acid, oleanolic acid, and ursolic acid identified in the pomegranate leaves were also found to be active, although only on the HIV-1 RT-associated RNase H function. This lead, therefore, to a special interest in ellagic acid and ellagitannins since their dual activity, on both enzymes, could be exploited in the development of derivatives with multi-target functions to avoid the use of several drugs with different activities. Our findings, therefore, suggest a possible use for and valorization of non-edible parts of $P$. granatum in line with the circular economy concept. Leaves, bark, and peels are in fact often considered to be agricultural wastes or byproducts; however, their enrichment in phytochemicals could be used in the development of drugs to treat HIV infection.

Supplementary Materials: The following are available online at https://www.mdpi.com/article/ 10.3390/plants10102124/s1, Figure S1: Representative LC-PDA profiles of PGL (A), PGB (B), and PGP (C) extracts $(\lambda=370 \mathrm{~nm})$, Table S1: Selected method for quantification and specifications, linearity range, R2, and calibration curve of the main compounds quantified in pomegranate extracts through HPLC-PDA-MS/MS.

Author Contributions: Conceptualization, A.M., C.S., and F.E.; methodology, A.C. (Angela Corona), A.C. (Alessia Caredda), and S.A.; investigation, C.S., A.M., F.E., R.L., S.A., and P.R.; resources, C.S., E.T., and P.R.; data curation, A.M., C.S., R.L., and F.E.; writing-original draft preparation, C.S., A.M., and F.E.; writing-review and editing, C.S., A.M., E.T., P.R., and F.E.; supervision, C.S., P.R., and A.M. All authors have read and agreed to the published version of the manuscript.

Funding: This research received no external funding.

Data Availability Statement: All data are presented in this report.

Conflicts of Interest: The authors declare no conflict of interest. 


\section{References}

1. Ismail, T.; Sestili, P.; Akhtar, S. Pomegranate peel and fruit extracts: A review of potential anti-inflammatory and anti-infective effects. J. Ethnopharmacol. 2012, 143, 397-405. [CrossRef]

2. Kandylis, P.; Kokkinomagoulos, E. Food applications and potential health benefits of pomegranate and its derivatives. Foods 2020, 9, 122. [CrossRef]

3. Ge, S.; Duo, L.; Wang, J.; GegenZhula; Yang, J.; Li, Z.; Tu, Y. A unique understanding of traditional medicine of pomegranate, Punica granatum L. and its current research status. J. Ethnopharmacol. 2021, 271, 113877. [CrossRef] [PubMed]

4. Wang, R.; Ding, Y.; Liu, R.; Xiang, L.; Du, L. Pomegranate: Constituents, bioactivities and pharmacokinetics. Fruit Veg. Cereal Sci. Biotechnol. 2010, 4, 77-87.

5. Orgil, O.; Schwartz, E.; Baruch, L.; Matityahu, I.; Mahajna, J.; Amir, R. The antioxidative and anti-proliferative potential of non-edible organs of the pomegranate fruit and tree. LWT-Food Sci. Technol. 2014, 58, 571-577. [CrossRef]

6. Elshafie, H.S.; Caputo, L.; De Martino, L.; Sakr, S.H.; De Feo, V.; Camele, I. Study of bio-pharmaceutical and antimicrobial properties of pomegranate (Punica granatum L.) leathery exocarp extract. Plants 2021, 10, 1-9. [CrossRef]

7. Chiocchio, I.; Mandrone, M.; Tomasi, P.; Marincich, L.; Poli, F. Plant secondary metabolites: An opportunity for circular economy. Molecules 2021, 26, 495. [CrossRef]

8. Howell, A.B.; D'Souza, D.H. The pomegranate: Effects on bacteria and viruses that influence human health. Evid. -Based Complementary Altern. Med. 2013, 606212. [CrossRef]

9. Balli, D.; Cecchi, L.; Khatib, M.; Bellumori, M.; Cairone, F.; Carradori, S.; Zengin, G.; Cesa, S.; Innocenti, M.; Mulinacci, N. Characterization of arils juice and peel decoction of fifteen varieties of Punica granatum L.: A focus on anthocyanins, ellagitannins and polysaccharides. Antioxidants 2020, 9, 238. [CrossRef]

10. Singh, B.; Singh, J.P.; Kaur, A.; Singh, N. Phenolic compounds as beneficial phytochemicals in pomegranate (Punica granatum L.) peel: A review. Food Chem. 2018, 261, 75-86. [CrossRef] [PubMed]

11. Tanaka, T.; Nonaka, G.-I.; Nishioka, I. Tannins and related compounds. XLI. Isolation and characterization of novel ellagitannins, punicacorteins A, B, C and D, and punigluconin from the bark of Punica granatum L. Chem. Pharm. Bull. 1986, 34, 656-663. [CrossRef]

12. Tantray, M.A.; Akbar, S.; Khan, R.; Tariq, K.A.; Shawl, A.S. Humarain: A new dimeric gallic acid glycoside from Punica granatum L. bark. Fitoterapia 2009, 80, 223-225. [CrossRef]

13. El-Toumy, S.A.A.; Rauwald, H.W. Two ellagitannins from Punica granatum heartwood. Phytochemistry 2002, 61, 971-974. [CrossRef]

14. Acquadro, S.; Civra, A.; Cagliero, C.; Marengo, A.; Rittà, M.; Francese, R.; Sanna, C.; Bertea, C.; Sgorbini, B.; Lembo, D.; et al. Punica granatum leaf ethanolic extract and ellagic acid as inhibitors of zika virus infection. Planta Med. 2020, 86, 1363-1374. [CrossRef]

15. Wu, S.; Tian, L. Diverse phytochemicals and bioactivities in the ancient fruit and modern functional food pomegranate (Punica granatum). Molecules 2017, 22, 10. [CrossRef]

16. Zhang, L.; Gao, Y.; Zhang, Y.; Liu, J.; Yu, J. Changes in bioactive compounds and antioxidant activities in pomegranate leaves. Sci. Hortic. 2010, 123, 543-546. [CrossRef]

17. Marques, L.C.F.; Pinheiro, A.J.M.C.R.; Araújo, J.G.G.; De Oliveira, R.A.G.; Silva, S.N.; Abreu, I.C.; De Sousa, E.M.; Fernandes, E.S.; Luchessi, A.D.; Silbiger, V.N.; et al. Anti-inflammatory effects of a pomegranate leaf extract in LPS-induced peritonitis. Planta Med. 2016, 82, 1463-1467. [CrossRef] [PubMed]

18. Salwe, K.J.; Sachdev, D.O.; Bahurupi, Y.; Kumarappan, M. Evaluation of antidiabetic, hypolipedimic and antioxidant activity of hydroalcoholic extract of leaves and fruit peel of Punica granatum in male Wistar albino rats. J. Nat. Sci. Biol. Med. 2015, 6, 56-62. [CrossRef] [PubMed]

19. Šavikin, K.; Živković, J.; Alimpić, A.; Zdunić, G.; Janković, T.; Duletić-Laušević, S.; Menković, N. Activity guided fractionation of pomegranate extract and its antioxidant, antidiabetic and antineurodegenerative properties. Ind. Crops Prod. 2018, 113, 142-149. [CrossRef]

20. Trabelsi, A.; El Kaibi, M.A.; Abbassi, A.; Horchani, A.; Chekir-Ghedira, L.; Ghedira, K. Phytochemical study and antibacterial and antibiotic modulation activity of Punica granatum (pomegranate) leaves. Scientifica 2020, 8271203. [CrossRef]

21. Khwairakpam, A.D.; Bordoloi, D.; Thakur, K.K.; Monisha, J.; Arfuso, F.; Sethi, G.; Mishra, S.; Kumar, A.P.; Kunnumakkara, A.B Possible use of Punica granatum (Pomegranate) in cancer therapy. Pharmacol. Res. 2018, 133, 53-64. [CrossRef]

22. Angamuthu, D.; Purushothaman, I.; Kothandan, S.; Swaminathan, R. Antiviral study on Punica granatum L., Momordica charantia L., Andrographis paniculata Nees, and Melia azedarach L., to human herpes virus-3. Eur. J. Integr. Med. 2019, 28, 98-108. [CrossRef]

23. Arunkumar, J.; Rajarajan, S. Study on antiviral activities, drug-likeness and molecular docking of bioactive compounds of Punica granatum L. to Herpes simplex virus-2 (HSV-2). Microb. Pathog. 2018, 118, 301-309. [CrossRef] [PubMed]

24. Haidari, M.; Ali, M.; Ward Casscells, S.; Madjid, M. Pomegranate (Punica granatum) purified polyphenol extract inhibits influenza virus and has a synergistic effect with oseltamivir. Phytomedicine 2009, 16, 1127-1136. [CrossRef]

25. Yang, Y.; Xiu, J.; Zhang, L.; Qin, C.; Liu, J. Antiviral activity of punicalagin toward human enterovirus 71 in vitro and in vivo Phytomedicine 2012, 20, 67-70. [CrossRef] [PubMed]

26. Neurath, A.R.; Strick, N.; Li, Y.Y.; Debnath, A.K. Punica granatum (Pomegranate) juice provides an HIV-1 entry inhibitor and candidate topical microbicide. BMC Infect. Dis. 2004, 4, 41. [CrossRef] 
27. Esposito, F.; Ambrosio, F.A.; Maleddu, R.; Costa, G.; Rocca, R.; Maccioni, E.; Catalano, R.; Romeo, I.; Eleftheriou, P.; Karia, D.C.; et al. Chromenone derivatives as a versatile scaffold with dual mode of inhibition of HIV-1 reverse transcriptase-associated Ribonuclease H function and integrase activity. Eur. J. Med. Chem. 2019, 182. [CrossRef] [PubMed]

28. Sanna, C.; Scognamiglio, M.; Fiorentino, A.; Corona, A.; Graziani, V.; Caredda, A.; Cortis, P.; Montisci, M.; Ceresola, E.R.; Canducci, F.; et al. Prenylated phloroglucinols from Hypericum scruglii, an endemic species of Sardinia (Italy), as new dual HIV-1 inhibitors effective on HIV-1 replication. PLoS ONE 2018, 13, e0195168. [CrossRef]

29. Esposito, F.; Tramontano, E. Past and future. Current drugs targeting HIV-1 integrase and reverse transcriptase-associated ribonuclease H activity: Single and dual active site inhibitors. Antivir. Chem. Chemother. 2014, 23, 129-144. [CrossRef]

30. Carcelli, M.; Rogolino, D.; Gatti, A.; Pala, N.; Corona, A.; Caredda, A.; Tramontano, E.; Pannecouque, C.; Naesens, L.; Esposito, F. Chelation motifs affecting metal-dependent viral enzymes: N0-acylhydrazone ligands as dual target inhibitors of HIV-1 integrase and reverse transcriptase ribonuclease h domain. Front. Microbiol. 2017, 8, 440. [CrossRef] [PubMed]

31. Corona, A.; Esposito, F.; Tramontano, E. Can the ever-promising target HIV reverse transcriptase-associated RNase H become a success story for drug development? Future Virol. 2014, 9, 445-448. [CrossRef]

32. Christ, F.; Debyser, Z. The LEDGF/p75 integrase interaction, a novel target for anti-HIV therapy. Virology 2013, 435, 102-109. [CrossRef]

33. Cherepanov, P.; Maertens, G.; Proost, P.; Devreese, B.; Van Beeumen, J.; Engelborghs, Y.; De Clercq, E.; Debyser, Z. HIV-1 integrase forms stable tetramers and associates with LEDGF/p75 protein in human cells. J. Biol. Chem. 2003, 278, 372-381. [CrossRef] [PubMed]

34. Bicchi, C.; Rubiolo, P.; Ballero, M.; Sanna, C.; Matteodo, M.; Esposito, F.; Zinzula, L.; Tramontano, E. HIV-1-inhibiting activity of the essential oil of ridolfia segetum and oenanthe crocata. Planta Med. 2009, 75, 1331-1335. [CrossRef]

35. Esposito, F.; Sanna, C.; Del Vecchio, C.; Cannas, V.; Venditti, A.; Corona, A.; Bianco, A.; Serrilli, A.M.; Guarcini, L.; Parolin, C.; et al. Hypericum hircinum L. Components as new single-molecule inhibitors of both HIV-1 reverse transcriptase-associated DNA polymerase and ribonuclease H activities. Pathog. Dis. 2013, 68, 116-124. [CrossRef]

36. Esposito, F.; Zinzula, L.; Maxia, A.; Tramontano, E.; Sanna, C. Inhibition of HIV-1 reverse transcriptase associated activities by the hydroalcoholic extract of Casimiroa edulis seeds. Nat. Prod. Res. 2011, 25, 1067-1073. [CrossRef]

37. Guzzo, F.; Russo, R.; Sanna, C.; Celaj, O.; Caredda, A.; Corona, A.; Tramontano, E.; Fiorentino, A.; Esposito, F.; D’abrosca, B. Chemical characterization and anti-HIV-1 activity assessment of iridoids and flavonols from Scrophularia trifoliata. Molecules 2021, 26, 4777. [CrossRef]

38. Sanna, C.; Rigano, D.; Cortis, P.; Corona, A.; Ballero, M.; Parolin, C.; Del Vecchio, C.; Chianese, G.; Saccon, E.; Formisano, C.; et al. Onopordum illyricum L., a Mediterranean plant, as a source of anti HIV-1 compounds. Plant. Biosyst. 2018, 152, $1274-1281$. [CrossRef]

39. Sanna, C.; Rigano, D.; Corona, A.; Piano, D.; Formisano, C.; Farci, D.; Franzini, G.; Ballero, M.; Chianese, G.; Tramontano, E.; et al. Dual HIV-1 reverse transcriptase and integrase inhibitors from Limonium morisianum Arrigoni, an endemic species of Sardinia (Italy). Nat. Prod. Res. 2019, 33, 1798-1803. [CrossRef]

40. Cuzzucoli Crucitti, G.; Métifiot, M.; Pescatori, L.; Messore, A.; Madia, V.N.; Pupo, G.; Saccoliti, F.; Scipione, L.; Tortorella, S.; Esposito, F.; et al. Structure-activity relationship of pyrrolyl diketo acid derivatives as dual inhibitors of HIV-1 integrase and reverse transcriptase ribonuclease H domain. J. Med. Chem. 2015, 58, 1915-1928. [CrossRef]

41. Martini, R.; Esposito, F.; Corona, A.; Ferrarese, R.; Ceresola, E.R.; Visconti, L.; Tintori, C.; Barbieri, A.; Calcaterra, A.; Iovine, V.; et al. Natural product Kuwanon-L inhibits HIV-1 replication through multiple target binding. ChemBioChem 2017, 18, 374-377. [CrossRef]

42. Romani, A.; Campo, M.; Pinelli, P. HPLC/DAD/ESI-MS analyses and anti-radical activity of hydrolyzable tannins from different vegetal species. Food Chem. 2012, 130, 214-221. [CrossRef]

43. Lantzouraki, D.Z.; Sinanoglou, V.J.; Tsiaka, T.; Proestos, C.; Zoumpoulakis, P. Total phenolic content, antioxidant capacity and phytochemical profiling of grape and pomegranate wines. RSC Adv. 2015, 5, 101683-101692. [CrossRef]

44. Wyrepkowski, C.C.; Da Costa, D.L.M.G.; Sinhorin, A.P.; Vilegas, W.; De Grandis, R.A.; Resende, F.A.; Varanda, E.A.; Dos Santos, L.C. Characterization and quantification of the compounds of the ethanolic extract from Caesalpinia ferrea stem bark and evaluation of their mutagenic activity. Molecules 2014, 19, 16039-16057. [CrossRef]

45. Gómez-Caravaca, A.M.; Verardo, V.; Toselli, M.; Segura-Carretero, A.; Fernández-Gutiérrez, A.; Caboni, M.F. Determination of the major phenolic compounds in pomegranate juices by HPLC-DAD-ESI-MS. J. Agric. Food Chem. 2013, 61, 5328-5337. [CrossRef]

46. García-Villalba, R.; Espín, J.C.; Aaby, K.; Alasalvar, C.; Heinonen, M.; Jacobs, G.; Voorspoels, S.; Koivumäki, T.; Kroon, P.A.; Pelvan, E.; et al. Validated method for the characterization and quantification of extractable and nonextractable ellagitannins after acid hydrolysis in pomegranate fruits, juices, and extracts. J. Agric. Food Chem. 2015, 63, 6555-6566. [CrossRef] [PubMed]

47. Sumner, L.W.; Amberg, A.; Barrett, D.; Beale, M.H.; Beger, R.; Daykin, C.A.; Fan, T.W.M.; Fiehn, O.; Goodacre, R.; Griffin, J.L.; et al. Proposed minimum reporting standards for chemical analysis chemical analysis working group (CAWG) metabolomics standards initiative (MSI). Metabolomics 2007, 3, 211-221. [CrossRef] [PubMed]

48. Swilam, N.; Nematallah, K.A. Polyphenols profile of pomegranate leaves and their role in green synthesis of silver nanoparticles. Sci. Rep. 2020, 10, 14851. [CrossRef] [PubMed] 
49. Siwe-Noundou, X.; Ndinteh, D.T.; Olivier, D.K.; Mnkandhla, D.; Isaacs, M.; Muganza, F.M.; Mbafor, J.T.; Van Vuuren, S.F.; Patnala, S.; Hoppe, H.; et al. Biological activity of plant extracts and isolated compounds from Alchornea laxiflora: Anti-HIV, antibacterial and cytotoxicity evaluation. South. African J. Bot. 2019, 122, 498-503. [CrossRef]

50. Promsong, A.; Chuenchitra, T.; Saipin, K.; Tewtrakul, S.; Panichayupakaranant, P.; Satthakarn, S.; Nittayananta, W. Ellagic acid inhibits HIV-1 infection in vitro: Potential role as a novel microbicide. Oral Dis. 2018, 24, 249-252. [CrossRef] [PubMed]

51. Nutan; Modi, M.; Goelb, T.; Das, T.; Malik, S.; Suri, S.; Singh Rawat, A.K.; Srivastava, S.K.; Tuli, R.; Malhotra, S.; et al. Ellagic acid \& gallic acid from Lagerstroemia speciosa L. inhibit HIV-1 infection through inhibition of HIV-1 protease \& reverse transcriptase activity. Indian J. Med. Res. 2013, 137, 540-548.

52. Kuzikov, M.; Costanzi, E.; Reinshagen, J.; Esposito, F.; Vangeel, L.; Wolf, M.; Ellinger, B.; Claussen, C.; Geisslinger, G.; Corona, A.; et al. Identification of inhibitors of SARS-CoV-2 3CL-pro enzymatic activity using a small molecule in vitro repurposing screen. ACS Pharmacol. Transl. Sci. 2021, 4, 1096-1110. [CrossRef]

53. Asres, K.; Seyoum, A.; Veeresham, C.; Bucar, F.; Gibbons, S. Naturally derived anti-HIV agents. Phyther. Res. 2005, 19, 557-581. [CrossRef]

54. Mohan, S.; Elhassan Taha, M.M.; Makeen, H.A.; Alhazmi, H.A.; Al Bratty, M.; Sultana, S.; Ahsan, W.; Najmi, A.; Khalid, A. Bioactive natural antivirals: An updated review of the available plants and isolated molecules. Molecules 2020, 25, 4878. [CrossRef]

55. Mehla, R.; Bivalkar-Mehla, S.; Chauhan, A. A flavonoid, luteolin, cripples HIV-1 by abrogation of Tat function. PLoS ONE 2011, 6, e27915. [CrossRef] [PubMed]

56. Li, B.W.; Zhang, F.H.; Serrao, E.; Chen, H.; Sanchez, T.W.; Yang, L.M.; Neamati, N.; Zheng, Y.T.; Wang, H.; Long, Y.Q. Design and discovery of flavonoid-based HIV-1 integrase inhibitors targeting both the active site and the interaction with LEDGF/p75. Bioorganic Med. Chem. 2014, 22, 3146-3158. [CrossRef]

57. Lan, P.; Chen, W.N.; Huang, Z.J.; Sun, P.H.; Chen, W.M. Understanding the structure-activity relationship of betulinic acid derivatives as anti-HIV-1 agents by using 3D-QSAR and docking. J. Mol. Model. 2011, 17, 1643-1659. [CrossRef]

58. Aiken, C.; Chen, C.H. Betulinic acid derivatives as HIV-1 antivirals. Trends Mol. Med. 2005, 11, 31-36. [CrossRef]

59. Kashiwada, Y.; Wang, H.K.; Nagao, T.; Kitanaka, S.; Yasuda, I.; Fujioka, T.; Yamagishi, T.; Cosentino, L.M.; Kozuka, M.; Okabe, H.; et al. Anti-AIDS agents, 30. Anti-HIV activity of oleanolic acid, pomolic acid, and structurally related triterpenoids. J. Nat. Prod. 1998, 61, 1090-1095. [CrossRef]

60. Lee, J.S.; Miyashiro, H.; Nakamura, N.; Hattori, M. Two new triterpenes from the rhizome of Dryopteris crassirhizoma, and inhibitory activities of its constituents on human immunodeficiency virus-1 protease. Chem. Pharm. Bull. 2008, 56, 711-714. [CrossRef] [PubMed]

61. Medina-O'donnell, M.; Rivas, F.; Reyes-Zurita, F.J.; Cano-Muñoz, M.; Martinez, A.; Lupiañez, J.A.; Parra, A. Oleanolic acid derivatives as potential inhibitors of HIV-1 protease. J. Nat. Prod. 2019, 82, 2886-2896. [CrossRef]

62. Nonaka, G.I.; Nishioka, I.; Nishizawa, M.; Yamagishi, T.; Kashiwada, Y.; Lee, K.H.; Dutschman, G.E.; Cheng, Y.C.; Bodner, A.J.; Kilkuskie, R.E. Anti-aids agents, 21: Inhibitory effects of tannins on HIV reverse transcriptase and HIV replication in H9 lymphocyte cells. J. Nat. Prod. 1990, 53, 587-595. [CrossRef]

63. Martino, V.; Morales, J.; Martínez-Irujo, J.J.; Font, M.; Monge, A.; Coussio, J. Two ellagitannins from the leaves of Terminalia triflora with inhibitory activity on HIV-1 reverse transcriptase. Phyther. Res. 2004, 18, 667-669. [CrossRef] [PubMed]

64. Weaver, J.L.; Pine, P.S.; Dutschman, G.; Cheng, Y.C.; Lee, K.H.; Aszalos, A. Prevention of binding of rgp120 by anti-HIV active tannins. Biochem. Pharmacol. 1992, 43, 2479-2480. [CrossRef]

65. Rubiolo, P.; Casetta, C.; Cagliero, C.; Brevard, H.; Sgorbini, B.; Bicchi, C. Populus nigra L. bud absolute: A case study for a strategy of analysis of natural complex substances. Anal. Bioanal. Chem. 2013, 405, 1223-1235. [CrossRef]

66. Corona, A.; Onnis, V.; Deplano, A.; Bianco, G.; Demurtas, M.; Distinto, S.; Cheng, Y.-C.; Alcaro, S.; Esposito, F.; Tramontano, E. Design, synthesis and antiviral evaluation of novel heteroarylcarbothioamide derivatives as dual inhibitors of HIV-1 reverse transcriptase-associated RNase H and RDDP functions. Pathog. Dis. 2017, 5, 1-10. [CrossRef]

67. Tintori, C.; Corona, A.; Esposito, F.; Brai, A.; Grandi, N.; Ceresola, E.R.; Clementi, M.; Canducci, F.; Tramontano, E.; Botta, M. Inhibition of HIV-1 reverse transcriptase dimerization by small molecules. ChemBioChem 2016, 17, 683-688. [CrossRef]

68. Esposito, F.; Sechi, M.; Pala, N.; Sanna, A.; Koneru, P.C.; Kvaratskhelia, M.; Naesens, L.; Corona, A.; Grandi, N.; di Santo, R.; et al. Discovery of dihydroxyindole-2-carboxylic acid derivatives as dual allosteric HIV-1 integrase and reverse transcriptase associated ribonuclease H inhibitors. Antiviral Res. 2020, 174, 104671. [CrossRef]

69. Corona, A.; Meleddu, R.; Esposito, F.; Distinto, S.; Bianco, G.; Masaoka, T.; Maccioni, E.; Menéndez-Arias, L.; Alcaro, S.; Le Grice, S.F.J.; et al. Ribonuclease H/DNA polymerase HIV-1 reverse transcriptase dual inhibitor: Mechanistic studies on the allosteric mode of action of isatin-based compound RMNC6. PLoS ONE 2016, 11, e014722. [CrossRef]

70. Tintori, C.; Esposito, F.; Morreale, F.; Martini, R.; Tramontano, E.; Botta, M. Investigation on the sucrose binding pocket of HIV-1 Integrase by molecular dynamics and synergy experiments. Bioorganic Med. Chem. Lett. 2015, 25, 3013-3016. [CrossRef] [PubMed] 